\title{
Influence of Upward Mobility and Organizational Culture on Employees' Perceived Quality of Work Life and Work Identification
}

\author{
Dr Masood ul Hassan ${ }^{1 *}$
}

\section{ABSTRACT}

The study was intended to examine the effect of upward mobility on employee's perceived quality working life and work identification of Engineers of Kashmir division. The sample consists of 300 Engineers whose age ranged from 24-58 years. Work identification was measured through a questionnaire developed by Shrivastava and Dolke (1978). Quality of working life and upward mobility was measured through the questionnaires developed by Shah and Ansari (2000). The data was analysed by the Multiple Regression method.

Keywords: Upward mobility, QWL (Quality Working of life), Organizational culture, Work Identification

Organizational culture as a whole and its various facets were taken in this study as predictor variable. The aspect of organizational culture has its origin in the very human relation movement that emerged in the mid-1920s and was at its peak during 1930's to 1950's in the form of human relation movement. But formal stress on the characteristic of organizational culture has not a long history. It is only since the last three or four decades that organizations in progress have been giving importance to organizational culture and its meaning expanded to cover such an organizational atmosphere that may provide supportive humanized work atmosphere creating will to work among employees without focusing on coercive means and strategies to get employees self motivated at work.

Sharma (1983) investigated the significance of organizational climate for employees' motivation and satisfaction and she observed that factors like grievance handling, recognition, opportunities for enlargement and progress and participative management have been found instrumental for healthy organization climate which subsequently enhances motivation and satisfaction of the job-

\footnotetext{
${ }^{1}$ Department of Education, Central university of Kashmir, India

*Responding Author

Received: January 1, 2017; Revision Received: February 2, 2017; Accepted: February 7, 2017

(C) 2017 Hassan M; licensee IJIP. This is an Open Access Research distributed under the terms of the Creative Commons Attribution License (www.creativecommons.org/licenses/by/2.0), which permits unrestricted use, distribution, and reproduction in any Medium, provided the original work is properly cited.
} 


\section{Influence of Upward Mobility and Organizational Culture on Employees' Perceived Quality of Work Life and Work Identification}

incumbents. Shrivastava and Pratap (1984) also found positive relationship between positive perception of organisational climate and job-satisfaction.

Of the various organizational success and development independent variables which are of our concern is that of 'upward-mobility'. It is human desire that wherever they are, they want to grow; hence, the work place in firms or organizations are not the exception. In organizations where people work and render their services aspire for 'upward-mobility' or promotion. Employees do not wish to receive one promotion in job-life-time, but it is an unending desire that only comes to an end only with retirement. The major purpose of upward - mobility is to offer employees better chances for utilizing their abilities, skills, knowledge that can benefit the organization, as well as, help fulfill employees their own goals too. Upward - mobility also helps in enhancing morale, loyalty and a sense of belongingness that all contribute to organizational effectiveness, growth and development. Employees' perception towards organizational promotional policies and the chances for moving to higher ranks in the organization has an important effect on employees' commitment towards the organization (Gaertner \& Nellen, 1989).

Vardi and Hammer (1977) investigated the rates and directions of inter organizational job mobility and perception of mobility requirements among 298 randomly selected rank and file employees. Findings highlighted that these variables differed by technology. Significant positive relationship of career experiences with expanded interest and effort were found. Positive Mobility experiences also contribute to the job satisfaction.

Khan and Azam (1992) examined the relative significance of performance, personality and socio-environmental factors in managerial promotions as perceived by executives of two organizations belonging to private and public sectors. Data were collected from executives of both organizations. Results revealed significant differences in the perception of some of the personality qualities, performance and socio-environmental factors in the promotion.

Ross (1994) designed his study to analyze the effect of satisfaction with promotional opportunities, satisfaction with promotion and reward evolution criteria (SWPREC), organizational commitment on job satisfaction and employees' expressed turnover intention. The sample of the study consisted of 64 internal audit supervisors and 62 non-supervisory professional staff- level auditors (their mean age were 29.8 and 28.5 respectively). Satisfaction with promotional opportunities showed direct positive effect on job satisfaction and indirect effect on turnover intentions for both sample groups. For supervisors, satisfaction with promotion opportunities had both direct and indirect effect on job satisfaction. For staff- level employees' satisfaction with promotion and reward evolution criteria had both direct and indirect effect on turnover intentions. It is also suggested that both satisfaction with promotion 


\section{Influence of Upward Mobility and Organizational Culture on Employees' Perceived Quality of Work Life and Work Identification}

opportunities and satisfaction with promotion and reward evolution criteria used in the promotion and rewarded system, had to be considered in developing a model of internal auditors' job satisfaction and turnover intentions.

The concept of identification was basically witnessed in Psychoanalytic theory. Freud (1949) described identification as "the endeavour to mould a person's own ego after the fashion of one that has been taken as a model". Most of the personality theories emphasize identification as a process to internalize social values during the process of socialization in childhood period (Sanford, 1955; Kagan, 1958; Kelman, 1958). According to Freudian view, children identify with their parents because of the influence that parents exert over the child's environment (Freud, 1949; Kagan, 1958; Kelman, 1958). According to Freudian view, children identify with their parents because of the influence that parents exert over the child's environment (Freud, 1949; Kagan, 1958). It is indeed, true that childhood experiences play very vital role in shaping and mastering the environment but identification at work comes from adult socialization process at work to which neo-Freudians have given much more importance Caldwell et al. (1990), Hoffman and Woether (2006), Lauver and Kristof-Brown (2001) have contended that at every stage people evaluate their work and organizations in order to fulfill their needs through meeting the demands of work and when personal qualities and skills allow individuals to meet organizational demand then most likely they are able to complete their assigned tasks more easily and quickly.

Quality of work life (QWL) is a significant issue for both employees and employers. It is important for employees as they spend a very significant portion of their lives on the job and the quality of work life has a bearing on quality of their lives. On the other hand, employers consider employees' QWL a serious issue that should be properly taken care of because QWL is found instrumental or vital means in achieving organizational goals, and attaining.

The most important resource of an organization is its employees, hence, improving QWL subsequently leads to motivation, satisfaction, and efficiency of employees. Similarly, it also helps in enhancing organizational productive profitability. Since, early 1970's, psychologists and managers have become interested in studying QWL. The contributions made by Herrick and Maccoby (1972), Taylor (1974), Davis and Chems (1975), Emergy and Emergy (1976), Miller (1977), and Carlson (1978) are worth considering. In India the work on QWL had begun in 1970's. The efforts made in this area by Ganguly and Joseph (1976), De (1977a, 1977b), Mehta (1976), Sinha (1977) and Joseph (1978), are to be appreciated. According to De (1980) most of the work on qualit of work in Indian setting is either in theoretical descriptive framework or in an action research context. Present scenario, work culture demands for dynamic, competitive, creative and self-motivated work force to meet the challenges of the mega competition of products. Hence, these force management to equip employees with more knowledge, skill, and ability in order to get them able for utilizing their potentials properly to the maximum extent. Of 


\section{Influence of Upward Mobility and Organizational Culture on Employees' Perceived Quality of Work Life and Work Identification}

all, HRD is the latest strategy that helps individuals to acquire knowledge, skill, competence, and create a sense of belongingness and these in conjunction get them more involved with their work and thereby increasing employees' motivation satisfaction, and organizational effectiveness in general at work place. Megginson (1974) viewed HRD as "a total knowledge, skills, creative abilities, talent and aptitudes of an organization's work force as well as the values, attitudes and beliefs of the individual involved".

\section{METHODOLOGY}

\section{Participants}

The study was conducted on 300 Engineers of Kashmir in the age of 24-58 years and for selecting appropriate sample, stratified-random sampling technique was adopted in conducting present investigation. In this sampling technique every individual had the equal probability be selected. It was an appropriate sampling technique that was warranted to be opted in the very context of present research problem.

\section{Instruments}

Work Identification Scale developed by Srivastava and Dalke (1978): was used to measure work identification. There are 12 items which are related to the two-facets of work identification i.e., (i) importance attached to work tract, and (ii) satisfaction of needs through work. Each facet contains 6 items. The respondents are required to respond on a 5-point scale by giving a score of 1 to highly disagreed statement and 5 to highly agreed statement.

Quality of Working Life (QWL): was measured by the scale developed by Shah (2000). The scale is a 5-point Likert type scale ranging strongly disagrees to strongly agree.

\section{Upward Mobility Questionnaire}

The scale developed by Shah and Ansari (2002) was used to measure upward mobility. This questionnaire consisted of nine items, out of which four were negatively phrased. The items measure employees' perception about their chances of advancement, fairness in the promotion policies of management, and the mode of promotion. In this Likert type questionnaire, responses were measured from Highly Disagreement ' 1 ' to Highly Agreement ' 5 '. Higher the score, more the employees' perception about the chance of their upward mobility in the organization.

\section{Organizational Culture Scale}

Organizational culture was measured with the help of organizational culture scale developed by Imtiaz and Ansari (2000). The twelve dimensions of scale are namely: fairness, mutual trust, openness, organizational climate, synergy, organizational environment, autonomy, work values, organizational belongingness, confrontation, pro-action and organizational loyalty as discussed above. The response-rating system as in organizational culture scale is 5-point response category. 
Influence of Upward Mobility and Organizational Culture on Employees' Perceived Quality of Work Life and Work Identification

The congruent validity of scale and validity coefficient is $r=.76$ which indicate that the test is highly valid. Therefore, organizational culture scale was confirmed as standardized scale.

\section{RESULTS AND DISCUSSION}

TABLE 4.1 Predictors of Quality of work Life ANOVA

\begin{tabular}{|l|l|r|r|r|l|}
\hline \multicolumn{1}{|c|}{ Model } & Sum of Squares & \multicolumn{1}{c|}{ df } & Mean Square & \multicolumn{1}{c|}{ F } & Sig. \\
\hline Regression & 78852.265 & 2 & 39426.133 & 204.836 & $.000 \mathrm{~b}$ \\
Residual & 57165.521 & 297 & 192.477 & & \\
Total & 136017.787 & 299 & & & \\
\hline Regression & 812424.500 & 3 & 27141.500 & 147.159 & $.000 \mathrm{c}$ \\
Residual & 54593.286 & 296 & 184.437 & & \\
Total & 136017.787 & 299 & & & \\
\hline Regression & 82838.274 & 4 & 20709.569 & 114.881 & $.000 \mathrm{~d}$ \\
Residual & 53179.513 & 295 & 180.270 & & \\
Total & 136017.787 & 299 & & & \\
\hline Regression & 83798.474 & 5 & 16759.695 & 94.359 & $.000 \mathrm{e}$ \\
Residual & 52219.312 & 294 & 177.617 & & \\
Total & 136017.787 & 299 & & & \\
\hline
\end{tabular}

Predictors: (constant), Organizational Culture, Cooperation, Organizational Loyalty, Autonomy Criterion variable: Quality of Work Life

Table - 4.1 highlights the details of F-values obtained by using ANOVA which clearly show that five predictor variables emerged as significant predictors of QWL These significant predictors are - 'Organizational culture', 'Organizational loyalty' - a dimension of Organizational culture, and 'Autonomy' - a dimension of Organizational culture as their F-values ranging from minimum $\mathrm{F}=90.359$ to $\mathrm{F}=204.836$ are found significant beyond .01 level of confidence. The levels of significance of these predictors are so high that these come - up for advocating strongly their relationship with QWL.

The above results reveal to fact that except the above three significant predictors and upward mobility remaining failed to exert their significant influence on QWL.

Table 4.2 Predictors of Work Identification ANOVA ${ }^{e}$

\begin{tabular}{|ll|r|r|r|r|c|}
\hline & Model & Sum of Squares & \multicolumn{1}{c|}{ df } & Mean Square & F & Sig. \\
\hline 1 & Regression & 3228.745 & 1 & 3228.745 & 84.015 & $.000 \mathrm{a}$ \\
& Residual & 11452.252 & 298 & 38.430 & & \\
& Total & 14680.997 & 299 & & & \\
\hline 2 & Regression & 3437.963 & 2 & 1718.982 & 45.409 & $.000 \mathrm{~b}$ \\
& Residual & 11243.034 & 297 & 37.855 & & \\
& Total & 14680.997 & 299 & & & \\
\hline 3 & Regression & 3634.456 & 3 & 1211.485 & 32.463 & $.000 \mathrm{c}$ \\
\hline
\end{tabular}

(c) The International Journal of Indian Psychology, ISSN 2348-5396 (e)| ISSN: 2349-3429 (p) | 21 
Influence of Upward Mobility and Organizational Culture on Employees' Perceived Quality of Work Life and Work Identification

\begin{tabular}{|rl|r|r|r|r|r|}
\hline & Model & Sum of Squares & df & Mean Square & F & Sig. \\
\hline & Residual & 11046.541 & 296 & 37.319 & & \\
& Total & 14680.997 & 299 & & & \\
\hline 4 & Regression & 3800.807 & 4 & 950.202 & 25.763 & $.000 \mathrm{~d}$ \\
& Residual & 10880.189 & 295 & 36.882 & & \\
& Total & 14680.997 & 299 & & & \\
\hline
\end{tabular}

a. Predictors: (Constant), Organizational culture

b. Predictors: (Constant), Organizational culture, Organizational loyalty

c. Predictors: (Constant), Organizational culture, Organizational loyalty, Flexibility

d. Predictors:(Constant), Organizational culture, Organizational loyalty, Flexibility, Employee management relations

\section{Criterion variable: Work Identification}

As shown in Table - 4.2 that work identification is found to be function of four significant predictor variables viz., organizational culture, organizational loyalty, and flexibility and employee management relations as the obtained $\mathrm{f}$ - values are rendered statistically significant beyond .01 level of confidence.

Table -4.2 contains coefficients (beta values) and t-values which are also found significant. As shown in the table, organizational culture, organizational loyalty, and flexibility have emerged to have their positive relationship with work identification where employee management relations is found to have negative relationship with work identification. Upward Mobility failed to show any significant influence on work Identification and on its dimensions

\section{Acknowledgments}

The author appreciates all those who participated in the study and helped to facilitate the research process.

Conflict of Interests: The author declared no conflict of interests.

\section{REFERENCES}

Caldwell, D.F., Chatman, J.A. \& O'Reilly, C.A. (1990). Building organizational commitment: A multiform study. Journal of Occupational Psychology, 63, 245-261.

Carlson, H.C. ( 1978). On quality of work life in General Motors, The Indian Journal of complex engineering factory. National Labour Institute, New Delhi. Continuing Education.

Davis, L.E., \& Chem,A.B. (1975). The quality of working life; problems, prospects and

De, N.R. (1977a). Diffusion of work system redesign on participative design in a large

De, N.R. (1980). Redesign of work system and quality of work life. Reading in Management, Allahabad, A.H. Wheeler

Emergy, F.E., \& Emergy, M. (1976). Participative design. Canberra

(C) The International Journal of Indian Psychology, ISSN 2348-5396 (e)| ISSN: 2349-3429 (p) | 22 
Freud, S. ( 1949). Group Psychology and the analysis of the ego. London: Hogarth.

Gaertner, K.N., \&Nollen, S.D.(1989). Career experiences, perceptions of employment practices and psychological commitment to the organization. Human Relations, 42, 975-991.

Ganguly, O.N., \& Joseph, J.S. (1976) . Quality of working life: work prospects and aspirations of young workers (Mimeo ), Centre labour Institute, Bombay attitude change. Conflict Resolution, 2, 51-60.

Herrick, N., \& Maccoby, M. (1972). Humanizing work: A priority goal of the 1970. Paper presented at the International Conference on the quality of working life, Arden House, New York, the Indian Journa/o/Social Work, vol. XLI (3 ), 1980.

Hoffman, B.J., \& Woether, D.J. (2006). A Quantitative review of the relationship between Person organization fit and behaviour outcomes. Journal of Vocational Behaviour, 68, 389-399.

Imtiaz, N., \& Ansari, S.A. (2000). Organisational culture as a determiner of job satisfaction and work commitment.A study of supervisors and middle level managers. Unpublished Ph.D. Thesis, A.M.U. Aligarh

Joseph, G.S. (1978). Quality of working life and job attitude of industries craftsman. Bombay Psychologist, I( 1 ), 28-34.

Kagan, J. ( 1958). The concept ofldentification, Psychological Review, 65, 296-305.

Kelman, H.C. ( 1961 ). Process of opinion change, Public Opinion Quarterly, 25, 57-78.

Khan, K. M., \& Azam, K. M. (1992). Managerial promotions: Perceptions of public and private sector executives. Indian Journal of Industrial Relations, 27(3), 299-308.

Lauver, K.J. \& Kristof-Brown, A (200 l). Distinguishing between employee's perception Management Review, Park Ridge, No. 11.

Megginson C. L. (1974). Personal and Human Resource Administration, pp.4.

Mehta, P. (1976). From economics to demarcate commitment: The role of worker participation. Vikalpa, 1(4), 39-46.

Miller, R.S. (l 977). Participative management, quality of work life and job enrichment of Person-Job and Person-Organization fit. Journal of Vocational Behaviour, 59, 454-470.

Ross, Q. (1994). An examination of promotion opportunities and evaluation criteria as mechanism for affecting internal auditor commitment, job satisfaction, and turnover intentions. Journal of Managerial Issue, 6(2), 176-194.

Sanford, N. (1955). The dynamics of identification. Psyclwlogica/ Review, 62, l 06- ! ! 8.

Sharma, B.R. (1983). Organisational climate and employer employee relations in India.”Abhigyan, pp. 45-59.

Sinha, J.B.P. (1977). Quality of working life in the Indian setting. Journal of Social and Economic Studies, 5(2), 235-247. Social Work, vol. XII, No. 3.

Srivastava, P.K., \& Dolke, A.M. (1978). Personality, organization and job correlates of identification with work and organization. Report submitted to Indian Council of Social Science Research, Project No. F. 1-25175. 
Taylor, J.C. (1974). Quality of work life, paper presented at conference of Changing business society relationships, USA. The Indian Journal a/Social Work, XII(3), Oct. 1980. the state of art. Vol. I, New York, The Free Press

Vardi, Y., \& Hammer, T.H. (1977). Inter-organizational mobility \& career perceptions among rank \& file employees in different technologies. Academy of Management Journal, 20(4), 622-634.

How to cite this article: Hassan M (2017), Influence of Upward Mobility and Organisational Culture on Employees' Perceived Quality of Work Life and Work Identification, International Journal of Indian Psychology, Volume 4, Issue 2, No. 88, ISSN:2348-5396 (e), ISSN:2349-3429 (p), DIP:18.01.062/20170402, ISBN:978-1-365-74161-6 